\title{
A CASE OF INDIfFERENCE? \\ Child Murder in Later Medieval England
}

\author{
Sara M. Butler
}

\begin{abstract}
Art historian Barbara Kellum's 1973 article on child murder in medieval England paints a picture of a world replete with ruthless and murderous single mothers who escaped the legal consequences of their actions due to an indifferent court system that chose to turn a blind eye to the deaths of young children. Despite the overstated tone of her work, it remains the most systematic study of child murder in the medieval English context. Employing a sampling of 131 instances of child murder (including 144 victims), drawn from royal and ecclesiastical courts from the late thirteenth to the early sixteenth centuries, the current investigation asks us to rethink these early conclusions. Infanticide was a felony in the Middle Ages and neither jurors nor royal officials treated child murder with indifference. Nevertheless, it is clear that both gender and marital status guided the courts in their decisions throughout the legal process in terms of indicting, prosecuting, and sentencing defendants in cases of child murder.
\end{abstract}

Tn 1517, Alice Ridyng, daughter of John Ridyng of Eton in the diocese of Lincoln, came to the realization that she was pregnant. For Alice, this was not a joyful revelation. Not only was she unmarried and without means of independent support, but a local clergyman had fathered her illegitimate child, thus she could not even expect to resolve her situation with a hasty wedding. For whatever reason, Alice chose not to pursue abortion through herbals bought from the local apothecary or midwife, even though the medieval English maintained a fairly tolerant attitude towards abortion. ${ }^{1}$ Alice never formally articulated the rationale for her decision not to have an abortion. Perhaps she did not recognize she was pregnant until quite late in the pregnancy, and then feared the possibility of prosecution or excommunication; perhaps she worried that an abortion might also endanger her life; perhaps she believed enlisting the help of others would expose her pregnancy and subject her to communal ridicule and disapproval. Instead, she opted for a less effective and infinitely more dangerous solution: concealment. She told no one about the pregnancy, not even her mother and father. Her deception was not altogether successful. Some women from Eton and Windsor suspected that she might be pregnant, but she always denied it saying, "something else was wrong with her belly." When it came time for labor, she chose perilously to give birth alone, without the assistance of a midwife, in her father's home. Within four hours of the birth, she placed her 
hand over her newborn son's mouth and suffocated him, and then buried him in a dung heap in her father's orchard. Her ghastly secret was exposed two days later when she was taken by the "women and honest wives" of Eton and Windsor and physically examined; her gelatinous belly and swollen, lactating breasts gave her away. They brought her before the bishop's officials at Lincoln where she confessed her sins, swearing on oath that she had "never been known carnally" by anyone other than the father of her child. Her spirit broken, she awaited judgment on her penance. ${ }^{2}$

The story of Alice Ridyng belongs to the category of those most shocking cases in English legal history. The image of the nurturing and self-sacrificing mother is so deeply ingrained in Western society that child murders committed by a mother, throughout history, have evoked horror and incredulity. For years, historians and sociologists have relied primarily on two explanations to make sense of such a seemingly senseless crime. First, they have explained infanticide (in particular) as a crime of desperation, branding it a woman's crime, and often specifically a singlewoman's crime. Poverty, insufficient access to effective contraception, and widespread censure of sexually active singlewomen have become the villains in this circumstance. ${ }^{3}$ Alice Ridyng's case is a paradigm of infanticide, incorporating many common assumptions about murdering mothers. As a singlewoman in the medieval period, it is unlikely that she would have been capable of supporting herself, let alone a growing child. ${ }^{4}$ If Alice had decided to raise her illegitimate son, both might fall prey to communal deprecation. ${ }^{5}$ Alice faced an embarrassing and possibly painful penance in the church courts, the boy had no claim to an inheritance, and little hope existed of compelling the father to make regular payments of child support. ${ }^{6}$ With legitimate concerns for the welfare of her child and his future livelihood, some might even describe Alice's actions as a "mercy killing." Alice's plight, while it is the more common representation of infanticide, is certainly not the only scenario historians have imagined. Poverty may have been an even more crucial determinant in the case of married mothers. The need to provide daughters with a dowry (maritagium) upon marriage may have convinced some parents that daughters were more of a burden than a blessing. At times, parents may have relieved themselves of this responsibility by less obviously illicit means, what some scholars have termed "homicidal" or "selective" neglect."

Desperation is not the only justification put forward to explain cases of child murder. Second, and more recently, insanity in its various guises (puerperal insanity, postpartum depression) has come to dominate historical studies of murdering mothers. Although the record of Alice Ridyng's confession does not describe her as having been insane, this was a common 
enough verdict in cases of medieval child murder also. A verdict of insanity may seem like the most humane approach to such an irrational crime; nonetheless, the merciful treatment of legally incompetent defendants has caused some to suggest that this finding merely "excuses" the crime. Art historian Barbara Kellum's pioneering work on child murder in medieval England, published in 1973, exposed "the casual nature and mild consequences of infanticide in late medieval England." ${ }^{8}$ Kellum concluded that royal officials rarely bothered to prosecute either infanticide or filicide, and justices and jurors treated those cases that did appear in the courts with lenience: specifically, Kellum argued that the courts viewed child-murdering mothers as mentally incompetent and thus awarded them pardons. Further compounding the argument, historian Barbara Hanawalt has noted that, under statute law, a mother was not even guilty of homicide in the killing of her infant until the mid-sixteenth century, thus medieval "jurors may have been unclear whether or not indictment was appropriate." ${ }^{\prime 9}$ Here, it is essential to note that Hanawalt focused on statute law; common law, by nature, was unwritten. Her assumption is clear: if sixteenth-century legislators felt the need to state that infanticide was, in fact, a felony, then it must not have been one before that time.

This article intends to revise these perceptions through an analysis of 131 instances of child murder (comprising 144 victims) drawn from the late thirteenth to the early sixteenth centuries in England. In particular, I will argue that infanticide was a felony in medieval England and that neither jurors nor royal officials treated child murder with indifference. In fact, there is no reason to believe that the English royal courts treated child murder as anything less than homicide. Not all current assumptions are groundless, however. Medieval jurors did adopt a gendered approach in indicting, prosecuting, and sentencing cases of child murder, and in general seem to have considered infanticide a singlewoman's crime. For the purposes of this article, "child murder" as a category is restricted to cases of infanticide by a parent (homicide of an infant, from newborns up to the age of one), and filicide (homicide of young children).

\section{The Records}

This article draws on a wide variety of sources in an effort to understand better the responsibility of the English courts with respect to child murder. Cases of this nature should have fallen under the jurisdiction of the royal courts. In spite of its felony status, legal historian Richard Helmholz's 1975 study has revealed that the church also addressed infanticide and even filicide because of its close supervision of family morality. ${ }^{10}$ Thus, any study 
of child murder must examine both environments. For the royal courts, this article examines records from various stages of the legal process: 1) the coroners' rolls, which record the findings of the county coroner and his jury upon examining the corpse and scene of the crime; 2) the eyre or assize rolls, recording the written indictments of grand jurors; and 3) gaol delivery rolls, which document the trials of the accused and note the final verdict in a case.

In order to provide insight into general English trends, this study examines two eyre rolls for each county across England. For two counties-Yorkshire and Essex - all records of royal indictment were included, that is, eyre and assize rolls, coroners' rolls, and gaol delivery rolls. ${ }^{11}$ Because Yorkshire and Essex represent both the northern and southern extremes of England with respect to England's legal center, and provide us with an examination of major urban centers (York and Colchester) as well as myriad rural hundreds, an especial focus on those two counties should offer a more inclusive perception of English approaches to child murder. A study of cases of child murder drawn from these regions captures both the reactions of the legal officials whose actions are subject to a high degree of supervision, as in the case of Essex, and those of Yorkshire, where officials were much more detached from royal control and prone to imaginative uses of the law. ${ }^{12}$ This article will occasionally draw also on cases that fall outside these parameters; however, those cases have not been included in any statistical analysis.

On the ecclesiastical side, a much less exhaustive search was conducted, the goal being primarily to shed some light on the kinds of cases that made their way into the courts of the medieval English church. Ecclesiastical cases derive from the ex officio act books of the northern and southern provincial courts, housed respectively at York Minster Library and the Canterbury Cathedral Archives. These act books record disciplinary cases brought forward by communities, and thus offer insight into collective perceptions. In addition, much use has been made of the printed act books from lower jurisdictional courts, notably those for the dean and chapter of Lincoln, the archdeaconry of Buckingham, and the deanery of Wisbech.

The grouping of cases that derive from these records do not represent the actual number of occurrences of child murders in England between the late thirteenth and early sixteenth centuries. Rather, the records under examination produce a sampling of cases that help us to achieve a better understanding of how royal officials and jurors addressed allegations of child murder. 


\section{A Case of Indifference?}

Of all homicides, child murder is the most easily concealed. Infanticides might easily be disguised as stillbirths, filicides as accidental deaths. When faced with a visibly grieving parent, the coroner's inquest jury may have felt it inappropriate to pry too extensively into the death of a child, and may have been more willing to accept the evidence at face value. Even so, timidity was not the standard approach. The records offer no indication that royal officials disregarded the deaths of children. Rather, royal officials made every effort to find out what happened, even in those cases where they had little to go on but a dead body. To cite a few examples: the record of the Devon eyre of 1281-1282 includes a brief note concerning an unusual case of natural death. William Pope and Richard le Mewy reportedly discovered the body of an aborted baby, not far enough along in the pregnancy for the sex of the child to be immediately apparent. Convinced that something horrific had happened to the child, they began asking around the village to determine exactly how the body had come to be lying out in the open. After much questioning, they learned that Alice daughter of Emeline gave birth to the child while suffering from an illness; the child was stillborn and buried illegally in a ditch. Sometime afterwards, the ditch flooded with water, unearthing the tiny body and forcing it from its resting place. Case closed. ${ }^{13}$ The court was not always capable of drawing such definite conclusions, and yet, as a 1343 case from Oxford might suggest, officials did the best they could, at a minimum performing a thorough physical investigation of the body. When the body of a female newborn was found dead in the river Thames by the mansion of the Friars Minor, inquest jurors failed to ascertain the identity of the perpetrators. They did determine, however, that the child was roughly half a day old and that she had not yet been baptized, judging from the fact that the navel was untied. ${ }^{14}$ Cases of this nature, although not plentiful, appear with some regularity among the records of the royal courts of medieval England. Neither coroners, sheriffs, nor jurors were apathetic to the corpses of infants or children found drowned in wells, ditches, or rivers. Sheriffs ordered investigations and, sometimes, local inhabitants pointed a finger at a suspect. When the child was a stranger to the village, more often than not the jurors were at loose ends to discover the cause of the death. Without any evidence to the contrary, jurors often resorted to declarations of misadventure (that is, accidental death). Other times, as in the death of a three-month-old boy found floating in Canterbury pool and recorded in the Kent eyre of 1293-1294, they declared it a homicide, but stated firmly that they did not know who had thrown the body into the pool. ${ }^{15}$ In any case, royal officials exhibited a steadfast and thorough approach in their 
investigations into the deaths of infants and children. They treated their deaths as they did those of grown men and women.

The resolve of royal officials to give equal treatment to the dead is vital to appreciate fully the medieval position on child murder. Perhaps inspired by Philip Ariès' hypothesis of parental indifference, medieval scholars have often clung to myths of rife child abuse. ${ }^{16}$ At the extreme, some scholars contend that cannibalism of children took place during famines. ${ }^{17}$ On a more balanced note, Hanawalt has posited that "corporal punishment was normal in dealing with children who misbehaved," and yet she cautions that "extreme reprimands came to community attention." 18 Indeed, the medieval church advocated the necessity of physical discipline. A popular exemplum that appeared often in educational tracts notes the story of a father who failed to beat his child for wrongdoings; eventually the child grew into a criminal and died on the gallows. ${ }^{19}$ Even the most uneducated of the peasantry could not have missed the message implicit in this tale. Gratian's Decretum (c. 1140) articulated this image more formally, describing a father's castigation of his children as an act of piety. ${ }^{20}$ This perspective is critical. Whether parents loved their children was not the issue at hand; as the law and literature defined it, a loving parent was one who knew when to use physical force to keep a child in line. ${ }^{21}$

Nevertheless, there were restrictions imposed on the nature of parental discipline. While the secular legal treatises were silent on the issue, the Gregorian Decretals (1234) limited the powers of parents to discipline their children in "a reasonable manner." ${ }^{22}$ However, few canonists expanded on the issue to clarify the medieval church's understanding of "reasonable" chastisement. The most lucid explanations of the limits of chastisement present an extreme perspective. In his Commentaria (c. 1378), Baldus de Ubaldis argued that it was lawful for a father to imprison his children in chains for the purpose of legitimate chastisement, although a child should not be punished maliciously or without reason. ${ }^{23}$ Discussing acceptable levels of parental coercion in marriage contracts, Thomas of Chobham in his Summa Confessorum (c. 1215) adopted an equally strong stance, noting that the "degree of violence and fear must be such that it could turn a stable man, such as fear of death or physical mutilation." 24

Despite the severity of these images, the legal evidence paints a more subtle picture. There was an explicit sense of limits to the violence deemed appropriate for a disciplinarian, even if the definition of those limits remained fuzzy. For example, a 1331 suit for restitution of conjugal rights from the diocese of Rochester required John de Waledene to welcome his wife Beatrice back into his home; for her part, the court ordered her to chastise her sons and daughter, "lest they should give her husband cause for of- 
fence. If she fails to do so, he may administer gentle chastisement." ${ }^{25}$ Most important still, medieval England did not tolerate parents who chastised a child to death. Few cases of this nature appear in the records; nonetheless, their existence confirms that medieval society did not condone it. A Yorkshire eyre of 1279-1281 includes the indictment of Elias of Sutton. Wishing to castigate his son Adam for consorting with a thief, he hanged Adam from a beam until he died. Elias then fled and the court's official outlawed him. ${ }^{26}$ In a 1329-1330 indictment, Alexander Heved of Buckby, Northamptonshire reportedly beat his son to death with a rod in an effort to chastise him. The sheriff arrested him, only to have him escape from prison soon after. ${ }^{27}$ Only one case seemingly condoned death by chastisement. The 1330-1331 indictment of Simon Hereward specifically notes that he beat his son Richard in order to discipline him; however, the father claimed he was unaware his son was suffering from an acute disease. The jury determined that the boy died from the disease, not the beating; thus, jurors acquitted the father. ${ }^{28}$ Could a father possibly have been that ignorant of his son's health? Or was this just a convenient explanation intended to acquit a man with whom the jury felt sympathy?

In each of these cases, the fathers of the dead themselves were victims also. Medieval England defined the paternal role by its authoritarian character. Sermons, law, and popular literature joined forces to bombard medieval men with images of failed paternity, the world turned upside down by a man's incompetence to govern his household, mocking men into keeping their families in order. ${ }^{29} \mathrm{~A}$ man who neglected to chastise his subordinates was responsible at law for their criminal or sinful actions and subject to fines or worse. Medieval society expected a man to exercise a firm grasp on his household; but how firm was too firm? In the case of Elias of Sutton, mentioned above, jurors must have identified hanging one's son as excessive chastisement; but Simon Hereward had beaten his son with an admirable goal, and if his son had been healthy, surely, his peers would have commended (rather than vilified) him for his actions. An all-male jury, familiar with the rigors of maintaining a well-run household, may have sympathized with a father whose attempts at discipline had gone sadly awry. For a jury, a loving father who disciplined his child as part of a moral upbringing may have been difficult at times to distinguish from a child murderer.

Although a less direct form of death, cases of parental negligence exemplify best the attentiveness of the medieval courts to child murder and their desire to hold someone accountable. Because the medieval church had jurisdiction over family matters, its courts were the ideal venue for addressing matters of parental negligence. Cases of this nature, while not 
abundant, make regular appearances in the English church courts. ${ }^{30}$ For example, the register of the bishop of Lincoln for the year 1418 includes a brief note to absolve John Ramett of Theddlethorpe and his wife Matilda. The court had previously excommunicated both spouses for their negligence in the drowning death of John's daughter, Alice. ${ }^{31}$ In the same diocese, similar accusations arose against Thomas Leeke. The mother of a male infant reportedly left the baby at Leeke's door, insisting that he was the child's father. Leeke denied the claim, and so the baby was taken to different places and maltreated until he eventually died..$^{32}$ The royal courts, by contrast, did not have the capacity to punish a death indirectly caused by the actions of a parent (or anyone else for that matter). Regardless, jurors ensured that reports of accidental deaths sometimes included reproachful statements about the failure of the parents to provide adequate supervision. For example, when a sow bit three-year-old John son of Richard Coke on the head and killed him, the jurors noted that this happened "out of want of custody." 33 Two-year-old Alice daughter of Henry Sawyer of Grafton fell into a well and drowned "through her father's negligence"; two-year-old Joanna daughter of Richard Bocher also drowned "because of poor custody." 34 One of the more abysmal cases comes from a Wiltshire eyre of 1281 . Isabelle of Bradford brought her unnamed one-year-old boy to the home of his father, Robert Hudde, in the ville of Clevancy. The record notes that Robert did not wish to admit the baby into his custody, even though Isabelle was determined to relinquish it to him. She left the baby; he ignored it; the baby died the following night. Jurors declared the boy's death accidental, but they were careful to underline that the parents' negligence caused his death. ${ }^{35}$ In most of these cases, the records emit a sense of dissatisfaction from a jury saddened over an unnecessary death, but whose hands are tied. In one case, the jurors ignored the law altogether. An Essex indictment from the year 1285 reports the finding of the body of one-year-old Adam son of Alan, found dead in the home of his father in the vill of Shoeburyness. The jurors stated the child's parents left the house with the child sleeping in his cradle and then failed to return. Without food, Adam eventually died. Alan was outlawed; his wife Agnes was waived. ${ }^{36}$ If Adam and Agnes had stood trial, it is doubtful whether royal justices would have permitted a conviction on the grounds of homicide. In their absence, jurors may have seen their actions as a tiny victory for children.

\section{Who Committed Child Murder?}

While the factors that drive a person to commit child murder differ significantly from case to case and are hidden mostly from the reader by 
the often mechanical entries in medieval legal records, the indictments do suggest the existence of a pattern relating to the nature of the crime. Indictments of overlaying (accidental suffocation of an infant while sleeping with an adult), infanticide, and filicide each produced defendants of a distinct variety. ${ }^{37}$ Here, it is vital to recognize what the legal records actually represent. They do not indicate the actual numbers of child murders that occurred in the medieval period; rather, they represent the number of accusations of child murders, and thus provide plentiful insight into communal perceptions of the kind of acts and people requiring legal regulation. The identities of child murderers, then, are interwoven with medieval attitudes about child murder and the role of the law in its regulation.

\section{Overlaying}

The phenomenon of overlaying has dominated the study of infant death in the medieval period since historian R. H. Helmholz's investigation into infanticide in the provincial court of Canterbury during the fifteenth century ${ }^{38}$ Although some scholars contend that overlaying was merely a polite fiction for deliberate infanticide,certainly in a cold climate such as medieval England's, sharing a warm bed with an infant whose body does not easily retain heat does not seem like such a ludicrous idea. ${ }^{39}$ Straw mattresses, cramped sleeping conditions, and poor ventilation may have contributed to the likelihood of a fatality, presumably part of the reason why medieval canonists persistently railed against mothers sharing their beds with infants. ${ }^{40}$ Cases of overlaying regularly (although not frequently) made their way into the ecclesiastical courts even though homicide was not part of the church's authority. Helmholz concluded that the church considered overlaying a form of accidental death through parental negligence, and good parenting fell squarely into the jurisdiction of the church courts.

Because common law required juries to report all accidental as well as felonious deaths, overlayings sometimes made their way into royal records. The king's courts, however, attest that the medieval English did not always presume negligence. On the contrary, the royal courts called upon jurors to recognize the possibility of deliberate suffocation. In the three cases of overlaying drawn from the royal records the outcomes varied. A Northamptonshire eyre of 1329-1330 notes that when Alice overlaid her three-week-old daughter Margaret, she immediately fled. The jury declared that she was not a suspect (that is, they considered the death accidental). The court permitted her to return. ${ }^{41}$ A Cumberland eyre from 1292-1293 notes a similar finding in the death of the twelve-week-old child of Margaret Kidefoth; Margaret also fled out of fear, but was not suspected by jurors. The court invited her to return. ${ }^{42}$ Compassion was not the rule. A 
Shropshire eyre of 1272 recounts the case of Margery of Purslow, who suffocated her one-year-old child while lying in bed and afterwards threw his body in the vineyard. She fled; the courts proceeded to exact her, and she was waived..$^{43}$ The flight of all three mothers is a good indication that the medieval English popularly believed a mother who overlaid her child was a murderer at law. In the final account, in particular, the jury's verdict is not surprising. The courts understood concealment in itself as an indicator of guilt; thus, jurors equated Margery of Purslow's disposal of her child's body with a confession of guilt.

It is striking that all three of the parents in these cases were mothers. Further, the records fail to state explicitly the marital status of all three women, leaving the distinct impression that all three were also single. Because law did not require the courts to document the marital status of a defendant before the 1415 Act of Additions, it is not always easy to discover whether the accused was married. How the records identify a woman can act as a useful guide to indicate marital status. Scribes usually referred to a married woman in relation to her husband and to a singlewoman by her father or some other identifier (that is, Alice wife of John Smith versus Alice daughter of John Smith or simply Alice of York). ${ }^{44}$ If single mothers were more prone to overlaying, it should not be surprising. Certainly, without the help of a partner, adolescent children, or a nurse to take shifts with a crying child during the night, a weary single mother might have been more inclined to calm a child in the simplest means possible: through physical contact. What is most significant here is that single mothers may also have been more vulnerable to indictment than were married mothers. Medieval England held little sympathy for singlewomen, especially those whose unmarried state was not spiritually motivated. Singlewomen were economically restricted and regular targets of sexual slander. ${ }^{45}$ The late medieval English, in particular, experienced a distinct sense of apprehension about singlewomen. Historian Marjorie McIntosh's study of the prosecution of social misbehavior in late medieval England groups singlewomen with young people, outsiders, and the poor as the leading triggers of social regulation. ${ }^{46}$ A pregnant singlewoman merely confirmed local suspicions. Representatives of the courts and the community probably believed single mothers were more deserving of public reprimands than were married mothers, especially in cases of negligent parenting. With so few cases of overlaying, this hypothesis remains tentative; but cases of infanticide, overall, would seem to indicate that single mothers were a cause for concern in later medieval England. 


\section{Infanticide}

Single mothers would seem to have overwhelmingly predominated accusations of general infanticide also. Of the twenty-eight cases of infanticide, jurors accused one married mother, one widow, one unknown woman, one priest, and sixteen mothers with no recorded marital status. ${ }^{47}$ In eight cases, officials found only the bodies of the infants, and no one knew who was responsible. ${ }^{48}$ At sixteen out of the nineteen cases where the perpetrator is known (or roughly 84 percent), there is good reason to believe that single mothers were significantly more likely to stand accused of infanticide than was anyone else. Although records rarely remark on motivation, the mother's unwed state accounted for some of the deaths. The episcopal court book for the diocese of Lincoln notes that in the year 1519 at Sutton in the Marsh, Sir John Wymark, a chaplain, impregnated young Margaret Haburgh. After she gave birth to the child, he threw the baby into the sea and Margaret moved to Kestevan..$^{49}$ Aumphlisa daughter of Maud widow of William the Clerk of Crauden had her illegitimate son killed by her mother immediately after birth. The mother and daughter stayed on in Crauden for eight days after the fact and then fled. The court fined the vill because the child's demise had been signaled by the hue and cry of a neighbor, and yet officials did not arrest them, perhaps a sign that the community itself may have empathized with the woman's plight. ${ }^{50}$ In the fifteenth-century case of Agnes wife of Simon Turnor of Lower Hardres, the only married woman accused of infanticide, it is noteworthy that she appeared in a church court. Thus, (as with Sir John Wymark mentioned above) she faced penance, while the rest of these women had the threat of execution with which to contend. ${ }^{51}$

The prominent role ostensibly played by singlewomen in medieval infanticide indictments substantiates assumptions about the importance of both economics and reputation. Although few accounts are as detailed as that of Alice Ridyng's, records of the homicides of newborns emphasize concealment of the birth and speed in dispatching the body, implying that these women hoped to hide evidence of a pregnancy they had never willingly accepted. The 1280 indictment of Cecilia atte Hethe is typical. Immediately after giving birth to a child, Cecilia twisted its neck and threw it in the water of Aughton. ${ }^{52}$ Some parents were more successful in veiling their identities than were others. The Kent eyre of 1293-1294 records a brief entry concerning a newborn boy, thrown into a well with two rocks hanging around his neck by a rope. Jurors did not know who might have done such a thing. ${ }^{53}$ Not all single mothers were so unfeeling. Perhaps inspired by the popular literary theme of foundlings who go on to lead a better life, some mothers seem to have wanted their children found alive. ${ }^{54}$ At least 
three mothers abandoned living newborns with varying results. The 1249 indictment of Basilia daughter of Christian of Wroxhall claims that she left her newborn in a ditch. Unfortunately, a dog discovered the baby, mauled it to death, and then dragged its dead body through the village. Basilia fled and was waived. ${ }^{55}$ A woman described merely as Alice daughter of Peter de A. appears in a notation for July of 1339 in the Court of the Dean and Chapter of Lincoln, accused of both fornication and the exposing of her unbaptized child. In this case, the child survived. Alice submitted to the process of compurgation; the court acquitted her, but ordered her to provide for the child. ${ }^{56}$ The child of Alice Mortyn did not have this kind of luck. A 1497 entry from the records of the archdeaconry of Buckingham report that Alice Mortyn hid her newborn in a bog, where the child eventually died owing to lack of nourishment. ${ }^{57}$ Two of these three cases appeared in the ecclesiastical, as opposed to royal, courts; the choice of venue may hint that medieval Englishmen interpreted exposing a child as a less deliberate method of infanticide than the more usual means of drowning or breaking a child's neck.

Far from a passive attitude, infanticide indictments offer faint clues to transmit the measure of distaste evinced by jurors in their handling of infanticides. Indictments usually omit the name of the baby (presumably, because it did not have one); in some cases, though, the roll specifically states that the child died without a name. When Maud Heylof killed her baby by placing it in a vat of oil and hiding the vat in a marshy area near the floodgate, her 1286 indictment expressly notes that the baby was without a name. ${ }^{58}$ Details of this nature are included to hint at motivation: this is a parent who never intended to keep her child, and thus is worthy of the full penalty of the law. Several records also describe the baby as unbaptized. ${ }^{59}$ Given the usual fears of eternal damnation that led most new parents to rush infants fresh from the womb to the nearest church, an emphasis on the failure of parents to do so was likely to paint an uncaring image and obliterate any hope of a merciful verdict handed down by a compassionate jury. ${ }^{60}$ Because indictments reflect accusations of infanticide, rather than actual numbers of infanticides, it would seem that jurors believed single mothers were most inclined to carry out infanticide. Presentment jurors who understood the need to limit family size may have considered a married woman's infanticide defensible, and thus failed to bring evidence of these deaths to the attention of royal officials. Jurors may also have been more willing to accept the death of a married woman's newborn as a stillbirth or even accidental, because she "lacked the 'essential' motive for infanticide-an illegitimate child." 61 The medieval records include only one case of infanticide in which a single mother claimed her child had been stillborn. 
The Suffolk eyre of 1240 notes the trial of Sabina de Coetingle who defended herself with allegations of both a stillbirth and temporary insanity; the jury was not sympathetic. They found Sabina guilty and sentenced her to burn, an especially painful form of death usually reserved for petty traitors and heretics. ${ }^{62}$ What is most striking about her case is that hers was the only instance of infanticide in which jurors entertained (however briefly) an insanity defense. The court's finding, then, would seem to suggest that lenience did not extend to singlewomen who killed their newborns.

\section{Filicides}

In cases of filicide, we find a much greater diversity of perpetrators. Jurors accused fathers and mothers in roughly the same numbers: fifty-one male defendants, forty-five female defendants. Single mothers also do not play as dominant a role. Of the forty-five female defendants appearing in the records, twenty appear to have been single, nineteen were married and six were widows. Roughly a third of filicides (thirty-one out of ninety-six) also involved allegations of mental instability. The concentration of insanity pleas in cases of filicides confirms that filicides belonged to a much different category of child murder than did infanticide, one that sometimes warranted a more sympathetic treatment of the defendant. Were jurors more willing to entertain insanity defenses in filicides out of pity for poor families engaging in belated family planning? The age-old argument that impoverished families performed female child murder in order to escape the burden of dowries, although appropriate for other nationalities (the early modern Chinese, for example), is not substantiated in the medieval English sample. ${ }^{63} \mathrm{~A}$ breakdown of the victims of filicide reveals that males dominated the grouping of victims at seventy-six boys, forty-three girls and twenty-five of unknown gender. Even in cases of infanticide (including overlayings) boys predominated: fifteen boys, three girls, fifteen of unknown gender. Nor is there reason to believe that female child murder was regularly disguised in the records as accidental deaths; as Hanawalt has observed, the sex ratio in accidental deaths is close, with young boys appearing marginally more frequently ${ }^{64}$

Although the courts accused both fathers and mothers regularly of filicide, jurors did not treat the sexes equally. Jurors' compassion, as well as their suspicions, divided along gendered lines. For example, indictments casting a child's death as accidental were invariably deaths carried out by fathers. In many cases, while jurors interpreted the child's death as an accident, the father's intentions nonetheless were far from honorable. For example, the Bedfordshire eyre of 1247 includes the indictment of John Folet, arrested for the death of his son Richard whom he beat to death with 
a rod. In his defense, John argued that he had actually meant to hit his wife, but when she fled he missed, and hit the child sleeping in his crib. The rod struck his six-month-old boy squarely on the head; he died instantly. The jury declared it a death by misadventure and acquitted John. ${ }^{65}$ Sometimes the assault was even less accidental. A Kent indictment from 1293-1294 recounts the death of Anabilla daughter of William the Forester, aged two. Her mother was carrying Anabilla home from the local tavern one night when an argument broke out between her parents. Wishing to strike his wife, William instead hit the young girl she was holding with a staff to the head so that she died. Unlike John Folet, however, he did not linger to explain his actions. William fled and was outlawed. ${ }^{66}$ William son of Ralph of Muscoates, the son of John Walrand, and twenty-week-old Christian daughter of John Berney of Colchester all lost their lives in similar circumstances. Each of these fathers fled and were outlawed. ${ }^{67}$ Other deaths sprang from domestic accidents: Jordan Juger claimed he was trying to slaughter the family pig when his two-year-old son Adam got too close to the axe; the king saw fit to pardon him for the death. ${ }^{68}$ Hugh Faber was trying to shoo his chickens off the back of his property with a rake when he accidentally struck his four-year-old daughter Eva in the head. The jury in his case declared misadventure. ${ }^{69}$

The outcomes of cases mercifully cast by jurors of presentment as accidental deaths were not set in stone; officials pardoned some fathers, outlawed some, and acquitted others. Even so, what is remarkable is that none of the records describes a mother's child murder in this manner. What does this tell us? Given the mother had primary responsible for the rearing of children under the age of seven, she was the most likely parent to kill her child accidentally during dangerous household activities, scalding with hot water or an ill-fated swing of the axe during the slaughter of a chicken. Why did jurors entertain defenses of accidental death in the case of fathers, but apparently not in the case of mothers? Two conclusions are possible. First, jurors found men's stories more convincing; they immediately dismissed a woman's defense of death by misadventure as lacking credibility and thus did not bother to record it as a serious explanation. Second, and more optimistically, while jurors chose to indict some fathers for the accidental deaths of their children, they did not do so with mothers. Responding to popular sentiments concerning the mother-child bond, jurors believed a mother's love was indisputable, except where the evidence was clear. Because the records are replete with cases of children who died during household accidents without laying blame at the feet of the lady of the household, the second conclusion would seem to be the more sound of the two. ${ }^{70}$

Numerous other indications support the hypothesis that jurors behaved more mercifully to murderous mothers than fathers. Jurors were 
appreciably more likely to record a mother's actions rather than a father's as having been carried out during a bout of insanity. Of the thirty-one defendants described in the records as having been mentally unstable at the time of the homicide, twenty-three were women, eight were men. Jurors also went to great lengths to ensure royal officials would pardon insane mothers. For example, Anabilla wife of William Carter of Bulcote is not only described as having been out of her mind when she killed her son and two daughters, jurors also noted that she was in a frenzy and feverish. ${ }^{71}$ In the case of Alice wife of Reginald of Tibthorpe, the jurors described her as having been in the grip of dementia and vexed for some time before strangling her daughter Agnes. The record goes on further to note she was lacking all sense and reason, and she could not discern between good and evil. ${ }^{72}$ Jurors simply did not go to such great lengths to describe male defendants as insane. The courts were also more likely to award mothers an outright acquittal: jurors acquitted in nine cases of child murder; in seven of these instances, the defendant was the victim's mother. The king's representatives pardoned mothers at a slightly higher rate than they did fathers. While only sixteen of the parents in the 131 cases of child murder were granted pardons, ten of those were mothers. Jurors also chose to remark upon only a mother's remorse. For example, the 1329 indictment of Maud widow of Mark le Waleys of Buthwell notes that when she killed her sons Thomas and Robert and daughter Anastasia she was in a fury and had been for a least a month before that time, and she remained mad for some time after. When she recovered her senses Maud was so distraught at what she had done that she wished to drown herself in a stank pond, and would have, had her neighbors not intervened. The jury in her case declared her non compos mentis; the court returned her to jail to await pardon from the king. ${ }^{73}$ The 1331 indictment of Goda wife of John Attebek recounts a comparable story. Goda slew her son John and daughter Beatrice while demented. The jury relates that she had since fallen into a permanent dementia and become a vagrant in the village of Horsham and that she had even tried to drown herself but had been prevented by her neighbors. The jury declared her insane; she returned to jail to await pardon from the king. ${ }^{74}$ Altogether, the evidence affirms that jurors were more likely to scrutinize the intentions of a murderous mother and to take mercy on her.

Certain groups of cases stand out from the rest. Although both mothers and fathers sometimes killed multiple children at one time, only fathers were responsible for simultaneously killing their spouses. While not common, the records include four such instances. The indictments exude a sense of condemnation. For example, an indictment from the Warwickshire eyre of 1285 reports that his conscience was clear when Adam Glede set fire to his 
home while his wife and son John were inside sleeping; both died. Adam fled and was outlawed. ${ }^{75}$ A similar fate awaited John de Cudelington. In 1261 he allegedly slew his two daughters Edith and Alice and his wife Maud by night in his home in the vill of Parendon. John fled at once and was outlawed. ${ }^{76}$ One of the few convictions awarded by jurors to child murderers was to Ralph Lanton, indicted in 1292 of killing his son Sampson and his wife Joanna before fleeing. Officials arrested Ralph and he was hanged soon after. ${ }^{77}$ Family massacres on this scale would seem to have been most typical of murderous fathers.

Given the secretive nature of most child murders, perhaps it is most astonishing that a few perpetrators had accomplices. When she killed her two children, Alice daughter of Robert of Benefield enlisted the assistance of both her sister, also named Alice, and Hugh son of Goscelin. All three of them fled; both Alices were waived and Hugh was outlawed..$^{78}$ When Beatrice Porter of Rise in Holderness killed her daughter Alice, she did so with the assistance of Robert Whit of Wandesforth. Both were hanged. ${ }^{79}$ Beatrice wife of William son of Alan of Kirton teamed up with her son Robert to murder her stepson William. Both Robert and Beatrice fled to churches immediately after the crime, confessed before the coroner and abjured the realm. ${ }^{80}$ Finally, an indictment from the 1272 eyre of Buckinghamshire states that when Alan le Park hanged his son William and threw his corpse in the water, Sara daughter of John de Eltecote assisted him. Alan was outlawed; Sara was waived ${ }^{81}$ Apart from Beatrice and her son, the records generally do not propose any indication of the relationship between killer and accomplice.

\section{What Happened to Child Murderers?}

Despite Kellum's contention that child murderers frequently received pardons and that royal officials treated the crime itself casually, the legal records indicate otherwise. ${ }^{82}$ Pardons were infrequently granted (16 out of 131 cases, or roughly 12 percent), and outright acquittals and declarations of misadventure were also exceptional (8 percent). The percentage of pardons awarded in cases of child murder is somewhat higher than for many other felonies (several studies have noted figures hovering around 3 or 4 percent); because of the high concentration of insanity pleas in child murders, however, this should not be unexpected..$^{83}$ Yet, even allegations of insanity were not a guaranteed means of escaping the gallows. More often than not, insanity defenses were persuasive: thirteen pardons were granted as well as four outright acquittals. However, jurors and justices did not regard all allegedly insane child murderers as legally incompetent. 
Jurors were entirely comfortable declaring simultaneously that a defendant was both insane and competent. Therefore, the 1342 indictment of Alice daughter of John son of Robert records that she was in a state of madness when she killed her daughter Joanna, at the same time it claims Joanna was "feloniously" slain (and thus, Alice was liable). Nonetheless, Alice still managed to receive a pardon. ${ }^{84}$ Not all insane child murderers were so lucky. At least one deranged parent was waived, another escaped custody (and presumably was eventually waived), one committed suicide, another was burned, and nine died in prison awaiting trial.

Even in cases of infanticide, the records evince no sense of lenience. Barbara Hanawalt has argued that because infanticide did not appear in statute law until the mid-sixteenth century, jurors did not realize it was an indictable offense. ${ }^{85}$ The outcomes of cases of infanticide nevertheless indicate that those involved in committing and prosecuting the offense believed infanticide was a felony. It is true that convictions were rare. Of the twenty-eight cases of infanticide (not including overlayings) only two were convicted. However, women accused of infanticide understood it as a serious crime. Why else would ten of these women have fled the law? The fact that jurors waived at least eight fleeing women establishes that they also considered infanticide a felony. When infanticide entered into statute law in the mid-sixteenth century, English legislators, notorious for their lack of originality, probably intended it as a clarification of existing practices, rather than the creation of new law.

In part, courts excused so few cases of child murder because the defendants seldom stood trial. Many child murderers (50 of the 131, or 38 percent) fled the scene; most flights ultimately ended in outlawry (41 of the 50, or 82 percent); four abjured the realm. While flight, outlawry, and abjuration may not seem fitting ends for an indicted murderer, relocation, and exile were not easy in a world suspicious of strangers and where wealth was measured by one's inheritance. Royal officials arrested and imprisoned at least nineteen others, but their cases appear to have never made it to trial-in fourteen of those cases, the defendant died in prison. With so few defendants actually standing trial, it is no surprise that only a few child murderers were convicted and executed (eight hangings, one burning).

\section{Conclusion}

In general, the sympathies of both jurors and the courts lay with the dead. The records give no sense that officials or jurors treated the death of children differently than they did adult deaths. In fact, the homicide of infants, in particular, sometimes required officials to go to much greater 
lengths in their investigations in order to reveal the identity of the perpetrator. Jurors never had to determine whether an adult had been baptized, but did so for dead infants. Some other common assumptions about child murder do hold true, however. Even in the Middle Ages, infanticide was understood primarily as a singlewoman's crime. Indictments describe mothers with no known marital status desperate to conceal evidence of their deliveries. Singlewomen were sexually suspect. A pregnant singlewoman (whose very existence confirmed communal fears of ungoverned women) might well wish to conceal all evidence of an unwanted pregnancy. For the very same reasons, jurors seem to have been more determined to hold single mothers accountable for their crimes. Filicide, on the other hand, was not a singlewoman's crime, nor was it even specifically a woman's crime. Juries regularly indicted fathers of filicide; fathers may even have sometimes escaped conviction simply because society expected a good father to discipline his child. In general, though, fathers were subject to less compassionate treatment than were mothers. Jurors were more likely to award mothers outright acquittals; mothers were also more frequently recipients of pardons. The very sanctity of the mother-child bond that heightened the shock value of these cases, at the same time, was a filicidal mother's saving grace. Many jurors believed strongly that for a mother to violate that bond, she must be insane.

The evidence also suggests that the medieval English did not employ child murder as a means of belated contraception. If poor families practiced child murder to limit the burden of female offspring, there is no evidence in the records. In fact, the records suggest just the opposite: girls had a greater expectation of surviving their childhoods than boys. Hanawalt has argued that "with infant mortality being estimated at 30 to 50 percent of the births, infanticide may have been completely 'unnecessary' to the society." ${ }^{86}$ In the absence of any disparity in the gender ratio, her explanation seems pertinent.

The outcomes of cases also refute Kellum's portrayal of the courts' lenience in their treatment of child murderers. Rarely did they excuse child murderers. Moreover, there is little reason to believe that royal officials were anything less than diligent. The records themselves cannot offer us firm indications of rates of child murder in later medieval England; nevertheless, they do strongly suggest that there are no grounds to argue, as Kellum has, that the "very commonality of infanticide and child murder . . . allowed them to be condoned even in court." 87

Because of the horrific nature of the crime, child murder in history is a subject from which many scholars have shied and yet about which most hold strong beliefs. In the early 1970s, articles published in the History of 
Childhood Quarterly by Kellum, historian Richard Trexler, and Helmholz all addressed the issue of medieval child murder, particularly in the form of infanticide. Helmholz's study, while far from positive in its representation of rates and prosecution of infanticide, at the very least envisioned an English church wholly concerned with child deaths at the hands of negligent parents. Both Trexler and Kellum, by contrast, depicted a world in which a woman tossing her baby into the nearest river would seem to have been a familiar sight. The popularity of infanticide in the Mediterranean, in particular, was cited by Trexler as the impetus spurring the establishment of foundling homes as early as the eighth century, an evolving trend that led to the creation of similar homes throughout late medieval Italian urban centers. ${ }^{88}$ Despite the ease of abandonment offered by these institutions, Trexler exposed a Florentine underworld of coldhearted unwed mothers evading scandal by murdering their (mostly female) children. According to Trexler, a secular law theoretically disturbed by infanticide, but in practice impotent and indifferent, also plagued Florence. The chief disparity with Kellum's work unearthed by Trexler was the predominance of nurses involved in the deaths of infants, a consequence of foundling hospitals teeming with unwanted children. Despite subtle developments in this field since that time (most impressively with historian Philip Gavitt's fascinating work on the role played by SIDS in medieval Florence), scholars have embraced without question the conclusions of this early contingent of scholars. Before we continue to condemn the rash and callous decisions of medieval single mothers, it is my hope that the conclusions of this article will demonstrate to us that it is time to rethink our earlier beliefs and investigate this important subject more systematically.

\section{Notes}

'John M. Riddle, Eve's Herbs: A History of Contraception and Abortion in the West (Cambridge, MA: Harvard University Press 1997), 100.

${ }^{2}$ M. Bowker, ed., An Episcopal Court Book for the Diocese of Lincoln 1514-1520 (Woodbridge, UK: Lincoln Record Society, 1967), 61:53-54.

${ }^{3}$ For example, see Shulamith Shahar, Childhood in the Middle Ages (London: Routledge, 1990), 126-39.

${ }^{4}$ See Sandy Bardsley, "Women's Work Reconsidered: Gender and Wage Differentiation in Late Medieval England," Past and Present 165 (1999): 3-29.

${ }^{5}$ Neil Cartlidge, “'Alas, I go with Chylde': Representations of Extra-marital Pregnancy in the Middle English Lyric," English Studies 79, no. 5 (1998): 395-414. Cartlidge observed that "these lyrics testify to a depth of anxiety about extra-marital 
pregnancy which surely indicates that for many women such an eventuality was a supreme disaster, both economically and socially" (411).

${ }^{6}$ R. H. Helmholz, "Support Orders, Church Courts and the Rule of Filius Nullius: A Reassessment of the Common Law," Virginia Law Review 63, no. 3 (1977): 431-48.

${ }^{7}$ Barbara Kellum, "Infanticide in England in the Later Middle Ages," History of Childhood Quarterly 1, no. 1 (1974): 372. R. C. Finucane, The Rescue of the Innocents: Endangered Children in Medieval Miracles (New York: Palgrave, 1997), 161.

${ }^{8}$ Kellum, “Infanticide in England," 367.

${ }^{9}$ Barbara A. Hanawalt, "Medievalists and the Study of Childhood," Speculum 77 (2002): 452.

${ }^{10} \mathrm{R}$. H. Helmholz, "Infanticide in the Province of Canterbury during the Fifteenth Century," History of Childhood Quarterly 1, no. 3 (1975): 379-90.

${ }^{11}$ This study examined cases drawn from the eyre and assize rolls (JUST 1), coroner's rolls (JUST 2) and gaol delivery rolls (JUST 3, but also those pertinent gaol deliveries appearing in KB 27). These records are housed at The National Archives, hereafter TNA, Kew, Surrey, England.

${ }^{12}$ See C.J. Neville, "The Law of Treason in the English Border Counties in the Later Middle Ages," Law and History Review 9 (1991): 1-30. Northern jurors used treason laws in an ingenious fashion to address issues of cross-border disputes.

${ }^{13}$ TNA JUST $1 / 184$, m. 33d.

${ }^{14}$ TNA JUST 2/129, m. 3; appears also in translation in H.E. Salter, ed., Records of Mediaeval Oxford: Coroners' Inquest, the Walls of Oxford, Etc. (Oxford: The Oxford Chronicle Company, 1912), 27.

${ }^{15}$ TNA JUST 1/374, m. 66d.

${ }^{16}$ Philippe Ariès, Centuries of Childhood: A Social History of Family Life, trans. Robert Baldick (New York: Alfred Knopf, 1962).

${ }^{17}$ Alexandre-Bidon and Didier Lett, Children in the Middle Ages: Fifth to Fifteenth Centuries (South Bend: University of Notre Dame Press, 2000), 35.

${ }^{18}$ Barbara A. Hanawalt, The Ties that Bound: Peasant Families in Medieval England (Oxford: Oxford University Press, 1986), 183.

${ }^{19}$ T.F. Crane, ed., The Exempla or Illustrative Stories from the Sermones Vulgares of Jacques de Vitry (London, 1890), 287:121. On the importance of fatherly discipline, see Trevor Dean, Crime in Medieval Europe 1200-1550 (Harlow, UK: Longman, 2001), 21.

${ }^{20}$ Decretum Gratianai, C. 5 q. 5 c. 3. 
${ }^{21}$ Eleanora C. Gordon, “Accidents among Medieval Children as seen from the Miracles of Six English Saints and Martyrs," Medical History 35 (1991): 160-62.

${ }^{22}$ R.H. Helmholz, "And were there children's rights in early modern England? The Canon Law and 'intra-family violence' in England, 1400-1640," The International Journal of Children's Rights 1, no. 2 (1993): 24.

26.

${ }^{23}$ Helmholz, "And were there children's rights in early modern England?,"

${ }^{24}$ Thomas Chobham, Thomae de Chobham. Summa Confessorum, trans. F. Bromfield (Louvain: Éditions Nauwelaerts, 1968), 142.

${ }^{25}$ Emphasis is my own. Charles Johnson, ed., Registrum Hamonis Hethe, Diocesis Roffensis, A.D. 1319-1352, pt. 3 (Woodbridge, UK: Canterbury and York Society, 1948), 455.

${ }^{26}$ TNA JUST $1 / 1078$, m. 9.

${ }^{27}$ TNA JUST $1 / 635$, m. 45.

${ }^{28}$ TNA JUST $1 / 166$, m. 36d.

${ }^{29}$ Sara M. Butler, The Language of Abuse: Marital Violence in Later Medieval England (Leiden: Brill, 2007), 54-59.

${ }^{30} \mathrm{On}$ parental negligence, see Helmholz, "Infanticide in the Province of Canterbury," 379-90.

${ }^{31}$ Margaret Archer, ed., The Register of Bishop Philip Repingdon 1405-1419 (Hereford: The Lincoln Record Society, vol. 74, 1982), 3:431.

${ }^{32}$ A. Hamilton Thomson, ed., Visitations in the Diocese of Lincoln 1517-1531 (Hereford: Lincoln Record Society, 1940), 1:60.

${ }^{33}$ TNA JUST $2 / 130$, m. 2d.

${ }^{34}$ TNA JUST 2/132, m. 9; TNA JUST 2/138, m. 4.

${ }^{35}$ TNA JUST 1/1005, PT 2, m. 139d.

${ }^{36}$ TNA JUST 1/247, m. 38; appears also TNA JUST 1/245, m. 43d.

${ }^{37}$ Some deaths classified in this study as the murder of an older child may also have been infanticides. The records often omit the age of the child. If the rolls recorded the victim as an infant (infans), I classified the death as an infanticide; if they recorded the victim as a child (puer), he/she fell into the category of a filicide.

${ }^{38} \mathrm{Helmholz}$, "Infanticide in the Province of Canterbury," 379-90.

${ }^{39}$ On overlaying as a polite fiction, see Gregory Hanlon, “L'infanticidio dei coppie sposati nella Toscana rurale, secoli XVI-XVIII," Quaderni Storici, 113, no. 2 (2003): 453-98. 
${ }^{40}$ Overlaying was also a common theme in miracles stories. Gordon, "Accidents among Medieval Children," 154.

${ }^{41}$ TNA JUST 1/635, m. 30.

${ }^{42}$ TNA JUST $1 / 135$, m. 18d.

${ }^{43}$ TNA JUST 1/737, m. 26; also appears TNA JUST 1/736, m. 29. Being waived was the female equivalent of being outlawed.

${ }^{44} \mathrm{I}$ have also taken a number of other factors into consideration. The record occasionally does not identify a woman by her husband, but he makes an appearance in the narrative as either a first finder or a bystander. I have also made the somewhat problematic assumption that a woman was married if a roll reports her as having several children, on the assumption that a singlewomen would have been incapable of supporting several illegitimate children.

${ }^{45}$ Ruth Mazo Karras, "Sex and the Singlewoman," in Singlewomen in the European Past, 1250-1800, ed. Judith M. Bennett and Amy M. Froide (Philadelphia: University of Pennsylvania Press, 1999), 127-45.

${ }^{46}$ Marjorie Keniston McIntosh, Controlling Misbehavior in England, 1370-1600 (Cambridge: Cambridge University Press, 1998), 191.

${ }^{47}$ These twenty-eight cases do not include cases of overlaying.

${ }^{48}$ TNA JUST 1/374, m. 66d; TNA JUST 2/129, m. 3; TNA JUST 1/829, m. 5d; TNA JUST 1/827, m. 7d; TNA JUST 1/374, m. 28d; TNA JUST 1/568, m. 30.

${ }^{49}$ Thomson, ed., Visitations in the Diocese of Lincoln 1517-1531, 1:83.

${ }^{50}$ W.M. Palmer, ed., The Assizes held at Cambridge, A.D. 1260: Being a condensed translation of Assize Roll 82 in the Public Record office, with an introduction (Linton, UK: Eagle Printing Works, 1930), 3.

${ }^{51}$ Canterbury, Y.1.11 Ex officio Act Book, 1468-74, fol. 322. Because John Wymark was a priest, his case belonged to the church courts, as did the crimes of any other member of a religious order.

${ }^{52}$ TNA JUST $1 / 784$, m. $18 \mathrm{~d}$.

${ }^{53}$ TNA JUST $1 / 374$, m. 28.

${ }^{54}$ For example, Marie de France, "Le Fresne," in her The lais of Marie de France, ed. and trans. Robert Hanning and Joan Ferrante (New York: Dutton, 1978). See chap. 10 of John Boswell's The Kindness of Strangers: The Abandonment of Children in Western Europe from Late Antiquity to the Renaissance (New York: Pantheon Books, 1988).

${ }^{55}$ TNA JUST 1/996, m. 28.

${ }^{56}$ L. R. Poos, ed., Lower Ecclesiastical Jurisdiction in Late-Medieval England: The Courts of the Dean and Chapter of Lincoln, 1336-1349, and the Deanery of Wisbech, 1458-1484 (Oxford: Records of Social and Economic History, 2001), 97. 
${ }^{57}$ Elizabeth M. Elvey, ed., The Courts of the Archdeaconry of Buckingham (Aylesbury, UK: Buckinghamshire Record Society, 1975), 183.

${ }^{58}$ TNA JUST $1 / 87, \mathrm{~m} .39$.

${ }^{59}$ TNA JUST 2/129, m. 3 (unknown child); Lower Ecclesiastical Jurisdiction, p. 97 (Alicia daughter of Peter de A.); TNA JUST 1/303, m. 68d (Matilda la Fermore de Horeford).

${ }^{60}$ Finucane, The Rescue of the Innocents, 43-5.

${ }^{61}$ Dana Rabin, “Beyond 'Lewd Women' and 'Wanton Wenches': Infanticide and Child-Murder in the Long Eighteenth Century," Writing British Infanticide: Child-Murder, Gender, and Print, 1722-1859, ed. Jennifer Thorn (Newark: University of Delaware Press, 2003), 56. Or, as Richard Trexler has asked, "How could one prove infanticide within the walls of the family home? Who would want to?" Richard C. Trexler, "Infanticide in Florence: New Sources and First Results," History of Childhood Quarterly 1, no. 3 (1973): 105.

${ }^{62}$ TNA JUST $1 / 818$, m. 47.

${ }^{63}$ William L. Langer, “Infanticide: A Historical Survey," History of Childhood Quarterly 1, no. 3 (1973): 354.

${ }^{64}$ Barbara A. Hanawalt, "Narratives of a Nurturing Culture: Parents and Neighbors in Medieval England," in 'Of Good and Ill Repute': Gender and Social Control in Medieval England (Oxford: Oxford University Press, 1998), 168.

${ }^{65}$ TNA JUST $1 / 4$, m. 27d.

${ }^{66}$ TNA JUST $1 / 374$, m. 8d.

${ }^{67 T N A}$ JUST $1 / 1109$, m. 21d; TNA JUST 1/1051, m. 37d; TNA JUST 2/33a, m. 11d.

${ }^{68}$ TNA JUST $1 / 184$, m. 43d.

${ }^{69}$ TNA JUST $1 / 1098$, m. 12.

${ }^{70}$ Barbara A. Hanawalt, "Childrearing among the Lower Classes of Late Medieval England," Journal of Interdisciplinary History 8, no. 1 (1977): 1-22.

${ }^{71}$ TNA JUST 1/683, m. 33d.

72TNA KB 27/335, m. 17d.

${ }^{73}$ TNA JUST 3/119, m. 14d.

${ }^{74}$ TNA JUST 3/125, m. 10.

${ }^{75}$ TNA JUST 1/956, m. 34.

${ }^{76}$ TNA JUST 1/40, m. 28. 
77TNA JUST 1/303, m. 65.

${ }^{78}$ TNA JUST $1 / 614 \mathrm{~B}, \mathrm{~m} .38$

${ }^{79}$ TNA JUST 3/83, m. 19/6.

${ }^{80}$ TNA JUST $1 / 497$, m. 15.

${ }^{81}$ TNA JUST $1 / 60, \mathrm{~m} .28$.

${ }^{82}$ Kellum, "Infanticide in England," 367 and 382.

${ }^{83}$ J. B.Given found a pardoning rate of 3.2 percent in his Society and Homicide in Thirteenth-Century England (Stanford: Stanford University Press, 1977), 96; Kathleen Garay found a pardoning rate of 3.05 percent in her "Women and Crime in Later Mediaeval England: An Examination of the Evidence of the Courts of Gaol Delivery, 1388 to 1409," Florilegium 1 (1979): 99; and in her volume examining the court of King's Bench's visit to Lincoln in 1396, E.G. Kimball found a pardoning rate of 4.3 percent (11 out of 255 felons); see Some Sessions of the Peace in Lincolnshire(Hereford: Lincolnshire Record Society,, v. 49 (Hereford, 1953), 1:li-liii.

${ }^{84}$ TNA JUST 3/135, m. 17d.

${ }^{85}$ See n. 9 above.

${ }^{86}$ Barbara A. Hanawalt, "Women before the Law: Females as Felons and Prey in Fourteenth-Century England," in Women and the Law, ed. D. Kelly Weisberg (Cambridge, MA: Harvard University Press, 1982), 1:177.

${ }^{87}$ Kellum, "Infanticide in England," 382.

${ }^{88}$ Trexler, "Infanticide in Florence," 99. 